\title{
ELECTORAL VIOLENCE AND NIGERIA'S 2007 ELECTIONS
}

\author{
Osisioma B C Nwolise \\ Dr Nwolise is Senior Lecturer in the Department of Political Science, \\ University of Ibadan, Ibadan \\ Tel: +08037013069 \\ e-mail: osynwolise@yahoo.com
}

\begin{abstract}
Nigeria is looked upon by many both in Africa and outside to give leadership in the best democratic practices. Unfortunately, since its independence in 1960, its electoral process has been marred by violence, the most extreme of which, until 2007, was the violence in the Western Region in 1965-1966, which ushered in the first military coup in the country. This paper examines the issue of electoral violence in the 2007 elections and concludes that it was the worst in the country's 47 years of electoral history. The reason is mainly that those who perpetrate the violence are never punished. Instead, they are protected, and their victims are denied justice. The solution, therefore, lies in enthroning the rule of law, investigating and punishing tin gods, and mobilising citizens to defend democracy, and insist that politicians, incumbent governments, and electoral administrators play by the rules.
\end{abstract}

\section{INTRODUCTION}

There can be no democratic election, democratisation, consolidation of democracy, growth in democratic culture or internalisation of best democratic practice in any country if electoral violence is prevalent. Equally, no peaceful, secure, free and fair civilian-to-civilian transfer of power can take place without first purging the electoral process and the country of such infestations of violence.

Violence limits people's participation in the electoral process and enables the imposition of candidates, programmes, and policies, which, in turn, engender violent reactions from losers and the electorate. Hence, Kean $(2004, \mathrm{p} 1)$ observed that violence 'is the greatest enemy of democracy'. 
Yet, as Albert (2007, p 132) notes, 'elections play an important role in the life of a nation. It is one essential way by which citizens choose their leaders, and by so doing, contribute meaningfully to the identification of the kind of development they would like to see.' Despite the important position occupied by elections in democracies and the need for secure, peaceful, free and fair elections for a stable society and sustainable democracy 'elections in Nigeria have been characterized by lots of violence, the most popular and most frequently referred to being the Western Region election crisis of 1965' (Ochoche 1997, p 17).

The history of electoral violence in Nigeria has been covered in the works of scholars like Akintola, Albert, Post \& Vickers, Lewis, Sklar, Diamond, Osaghae, Mitee, and Kolawole. These studies by both Nigerians and foreign authors working at different times and spanning more than 40 years reinforce Albert's assertion that 'electoral violence resulting from representational, campaign, ballotting, and results conflicts, has been a terminal problem of Nigerian politics since the 1950s' (2007, p 132).

The task of this paper is to examine electoral violence in Nigeria's April 2007 elections. In pursuing this objective the paper traces the history and evolution of electoral violence in Nigeria; and gives an overview of the 2007 elections. The paper also contemplates the causes of electoral violence and why the ugly phenomenon has persisted in the country. Finally, it suggests strategies for ridding the country of electoral violence in order to encourage effective citizen participation in elections and to promote democratic consolidation, and a stable polity.

The study is significant at this point in Nigeria's national history for many reasons. First, it is very timely, as President Yar'Adua's administration has set up an electoral reform panel in an effort to rid Nigeria and its electoral process of corruption, fraud, and violence. The study is expected to inform the panel, and also to inform policy. Second, for Nigeria to survive as a multi-ethnic and multireligious nation and see real peace, security, unity, democracy and development, it must rid itself of electoral violence. Third, Nigeria as a significant nation, in Africa at least, needs to lead in best democratic practices. This it cannot do without exorcising electoral violence from its electoral process and system. As this author painfully remarked in a newspaper article immediately after the 2007 April general elections: 'We as Nigerians have failed again to give leadership to Africa in upholding the best democratic practices, and encouraging democratic forces all over the world' (Nwolise 2007, p 65).

\section{CONCEPTUAL DISCOURSES}

It is necessary to define three concepts: election, violence, and electoral violence. 


\section{Election}

To the average person in the street election is the selection of someone for a position. On a higher intellectual plane election is defined as 'the process of selecting the officers or representatives of an organization or group by the vote of its qualified members' (quoted in Nwolise 2007). Such an election may be in a university seeking a vice-chancellor, a corporate organisation choosing a chairman, a political party conducting its primaries to choose its standard bearer for a presidential contest, a nation wanting to choose its president, or an international organisation selecting its secretary general.

Akzin (1960, pp 706-8) informs us that elections have technical and social significance. In the technical sense, they are the process through which an office or a post is assigned to a person by an act of volition that requires the simultaneous expression of many people's opinions. In the social sense an election is the process by which a person is linked to an office through the due participation of the people who will bear the weight of his or her authority. It is this social aspect of elections that generates the idea of governing a society with the consent of the governed, and this boils down to democracy and distinguishes election from appointment (Akzin 1960, pp 706-8). We should add here Mayo's view (1960, p 73) that the main 'purpose of the whole electoral process is to produce a government invested with legitimacy'.

This point should be noted by heads of state, political parties, and chairpersons of election administrative bodies, for they must know that any election result which is contrary to the votes cast by the people automatically and naturally creates a legitimacy crisis.

Thus, elections are significant because they convey legitimacy to leaders and governments when they are democratically conducted but generate legitimacy crises when persons and governments that are not the true choice of the people are foisted on them.

\section{Violence}

There are scholars who perceive violence in terms of the use of force against persons and objects. For example, Corsini (1999) defines violence as the manifestation of hostility and rage through physical force directed against persons or property. Degenaar's view is that violence is 'the intentional application of extreme force against $\mathrm{X}$ in such a way that it is destructive of objects and physically injurious to animals and persons' (1990).

There are also scholars who perceive violence as the illegitimate use of force. For example, Hook (1934, p 264) defines violence as the 'illegal employment of 
methods of physical coercion for personal or group ends' and Wolff $(1969, \mathrm{p} 2)$ asserts that 'violence is the illegitimate or unauthorized use of force to effect decisions against the will or desire of others'. There are other scholars, Audi (1971, pp 72-3), for instance, who maintain that violence, no matter whether legally or illegally applied, is 'the unjustifiable use of force'.

The common element among the scholars cited above, whether they see violence as legitimate or illegitimate, justified or unjustified, is that violence is the use of physical force against persons or objects.

It is, however, important to observe, as Hook and Wolff, respectively, hold, that not all violence is illegitimate, for this would mean that the masses could not react against unjust and unpopular government policies and actions. It also means that only government actions can be legitimate, even if hundreds of citizens are massacred or elections are rigged beyond recognition. With this in mind Leiden \& Schmitt $(1968, \mathrm{p} 3)$ define violence, especially political violence, as 'a disturbance to the political equilibrium of a state, a breakdown of its political system'. Ted Robert Gurr (1970, pp 1-2), in the same value-neutral sense, conceptualises violence as 'all collective attacks within a political community against the political regime, its actors - including competing political groups as well as incumbents - or its policies'. Gurr's definition, however, assumes that only the masses can wage violence against government, and not vice versa, which is not correct. Government and its agents can, and do, wage violence against the people and their property. Again, not all violence leads to a breakdown in a state's political system, while a demonstration may also disturb a state's political equilibrium.

Before resolving the issue of the conception of violence it is critical to explore its forms. Almost all the above definitions present violence as a physical variable, whereas scholars like Galtung (1991, pp 10-12) believe it can be psychological and structural as well as physical. Physical violence involves physical assault such as attacks against persons and properties. Psychological violence involves generating and living in fear, terrorising people, or publishing abusive material directed against people. Structural violence, which, according to Galtung, is usually indirect, but may be more destructive than physical and psychological violence, involves, among other factors, political repression, economic exploitation, and deprivation of rights such as freedom of choice (Galtung 1991, pp 10-12).

The implication is that violence cannot and should not be perceived as mere physical attacks, but should instead be regarded holistically as incorporating physical, psychological, and structural dimensions. Hence, in this paper violence is considered to be any form of organised or spontaneous action or threat effected by the people or by government or its agents to occasion harm, undue advantage, injury or destruction, with the aim of influencing or achieving a desired objective. 
There have been attempts to explain violence, the most popular of which is the frustration-aggression theory put forward by Sigmund Freud (1939) and popularised by Hollard, Doob, Miller et al (1939). The theory holds that the occurrence of aggressive behaviour always presupposes the existence of frustration.

\section{Electoral Violence}

Based on the old, narrow concept of violence as a physical phenomenon, electoral violence has previously been regarded as physical violence unleashed by political thugs used in election rigging processes or by the masses of the people reacting against the theft of an election. Methods used by the former include the physical assault of opponents of their paymasters, attacks on properties, shootings, kidnappings, ballot-box snatching, assassination, and so on, and by the latter include riots, the beating up of electoral officials and the police, setting public property alight, burning tyres in the streets to disrupt traffic, and so on.

Albert (2007, p 136) observes that 'extant literature on electoral violence in Nigeria focuses on this type of violence'.

However, following the reconceptualisation of violence as having not merely a physical dimension but also psychological and structural dimensions, Albert (2007, p 133) defines electoral violence as 'all forms of organized acts or threats physical, psychological, and structural - aimed at intimidating, harming, blackmailing a political stakeholder before, during, and after an election with a view to determining, delaying, or otherwise influencing an electoral process'. Ochoche concurs, stating that electoral violence is not only a physical phenomenon but can also be structural. He noted that there are many stages in an election and each stage can be abused, manipulated, violated, corrupted, or distorted. ${ }^{1}$ In his words:

At any of the stages, the violence could be physical or structural. In other words, electoral violence must not be seen in physical terms alone. Any attempts at any stage of the electoral process to corrupt, influence, or determine the outcome of an election beyond what it would have been objectively, does damage to the election and could be said to amount to electoral violence. ${ }^{3}$

Ochoche 1997

1 These stages include: registration of voters, demarcation of electoral boundaries, registration of parties and contestants, location of polling booths and collation centres, organisation of party primaries, campaign, voting, counting of votes, announcement of results, and litigation in electoral tribunals or courts. 
Having noted the above, this discourse defines electoral violence as the use of physical force, psychic terror tactics, or official bureaucratic machinery to pursue improper electoral ends.

Table 1

Some Components of the Three Dimensions of Electoral Violence

\begin{tabular}{|c|c|}
\hline Dimension & Components \\
\hline \multirow[t]{12}{*}{ PHYSICAL } & $\begin{array}{l}\text { Physical assault on individuals during } \\
\text { campaign, elections and when election } \\
\text { results are released. }\end{array}$ \\
\hline & $\begin{array}{l}\text { Assassination of political opponents or } \\
\text { people perceived as a threat to one's } \\
\text { political ambition. }\end{array}$ \\
\hline & $\begin{array}{l}\text { Burning down of public or opponents' } \\
\text { houses or cars. }\end{array}$ \\
\hline & Shooting, shoot-outs. \\
\hline & Killing of individuals. \\
\hline & $\begin{array}{l}\text { Partisan harassment by security agents, } \\
\text { arrests, forceful dispersal of rallies, or } \\
\text { shooting, wounding or killing of people. }\end{array}$ \\
\hline & Kidnappings and hostage-taking. \\
\hline & Bombing of infrastructure. \\
\hline & $\begin{array}{l}\text { Forceful disruption by thugs of political } \\
\text { and campaign rallies. }\end{array}$ \\
\hline & $\begin{array}{l}\text { Destruction of ballot boxes and ballot } \\
\text { papers by thugs or partisan security } \\
\text { agents. }\end{array}$ \\
\hline & $\begin{array}{l}\text { Armed raids on voting and collation } \\
\text { centres, and snatching of ballot boxes } \\
\text { and papers from polling agents. }\end{array}$ \\
\hline & Free-for-all fights. \\
\hline \multirow[t]{3}{*}{ PSYCHOLOGICAL } & $\begin{array}{l}\text { Threats against and harassment by } \\
\text { security agents of opponents of the } \\
\text { ruling regime or party, which create } \\
\text { political apathy. }\end{array}$ \\
\hline & $\begin{array}{l}\text { Shoot-on-sight orders that breed fear in } \\
\text { voters. }\end{array}$ \\
\hline & $\begin{array}{l}\text { Terror inflicted by political } \\
\text { assassinations, which makes people }\end{array}$ \\
\hline
\end{tabular}




\begin{tabular}{|c|c|}
\hline & $\begin{array}{l}\text { scared to participate in politics or } \\
\text { elections. }\end{array}$ \\
\hline & $\begin{array}{l}\text { Publication or broadcast of abusive, } \\
\text { insulting, or intimidating material or } \\
\text { advertorials. }\end{array}$ \\
\hline & $\begin{array}{l}\text { Threats to life through phone calls, text } \\
\text { messages, etc. }\end{array}$ \\
\hline \multirow[t]{17}{*}{ STRUCTURAL } & $\begin{array}{l}\text { Coercion of citizens by government to } \\
\text { register or vote. }\end{array}$ \\
\hline & Exclusionary acts and policies. \\
\hline & Discriminatory acts and policies. \\
\hline & $\begin{array}{l}\text { Unequal opportunities for political } \\
\text { parties and candidates. }\end{array}$ \\
\hline & $\begin{array}{l}\text { Deliberate changes in dates, venues, or } \\
\text { times of events to the disadvantage of } \\
\text { others. }\end{array}$ \\
\hline & $\begin{array}{l}\text { Partisan delimitation of electoral } \\
\text { constituencies and location of polling } \\
\text { booths. }\end{array}$ \\
\hline & $\begin{array}{l}\text { Excessive fees for collecting party } \\
\text { nomination forms. }\end{array}$ \\
\hline & Unfree campaigns. \\
\hline & $\begin{array}{l}\text { Reliance on money and brute force } \\
\text { instead of moral integrity and } \\
\text { competence. }\end{array}$ \\
\hline & Restraints imposed on voters. \\
\hline & $\begin{array}{l}\text { Use of the incumbency factor to give } \\
\text { undue advantage to some candidates. }\end{array}$ \\
\hline & $\begin{array}{l}\text { Announcement of false or fraudulent } \\
\text { results. }\end{array}$ \\
\hline & $\begin{array}{l}\text { Lengthy delays in announcing election } \\
\text { results. }\end{array}$ \\
\hline & $\begin{array}{l}\text { Absence of (adequate) voting materials } \\
\text { and election results forms. }\end{array}$ \\
\hline & Delays in voting. \\
\hline & $\begin{array}{l}\text { Absence of electoral officers from polling } \\
\text { booths. }\end{array}$ \\
\hline & $\begin{array}{l}\text { Partisan behaviour of police and other } \\
\text { security agents. }\end{array}$ \\
\hline
\end{tabular}




\section{HISTORY AND EVOLUTION OF ELECTORAL VIOLENCE IN NIGERIA}

Elections were introduced in Nigeria in 1922 with the introduction of the Clifford Constitution, which provided for voting in Lagos and Calabar, as well as the emergence of political parties, beginning with Sir Herbert Macaulay's Nigerian National Democratic Party (NNDP). The early elections were relatively violence free.

However, from the 1959 elections, which ushered in independence in 1960, the country began to experience exacerbated electoral violence, orchestrated by the 1954 Macpherson Constitution, which confirmed the regionalism introduced by the Richard Constitution of 1946, as the basis for running Nigeria's federal system. The equation of key ethnic boundaries with regional boundaries (north for Hausa-Fulani, west for Yoruba, and east for Igbo) set the stage for violent electoral battles between the three major ethnic groups, each of which oppressed minority groups politically and economically.

The 1952 political maneouvres in the Western Regional House of Assembly, which denied Dr Nnamdi Azikiwe (an Igbo) representation set the stage and heightened the tempo of electoral violence as Azikiwe abandoned the search for political fortune in the west and returned to his eastern base of origin, where he had to displace Chief Eyo Ita, a minority man, to become premier, an act which did not go down well with the eastern minorities, just as the Igbo did not take kindly to their candidate being pushed out of the west.

During the 1959 general elections there were physical, psychological, and structural forms of violence, taking the form of thuggery, and election rigging. Even before the vote count was completed the then governor general, Sir James Robertson, had asked Sir Abubakar Tafawa Balewa of the Northern People's Congress (NPC) to form a government, as the British wished to hand over power to their long-favoured ally, the north. Thus, even before Nigeria's independence, electoral violence had taken root in the country. However, since every nationalist just wanted the white man out so the country could gain independence, there was little protest against Robertson's actions from the other key political parties the National Council of Nigeria and Cameroons (NCNC), as it was then called (led by Dr Azikiwe); the Action Group (AG), led by Chief Awolowo; and the Northern Elements Progressive Union (NEPU), led by Mallam Aminu Kano.

Real electoral violence can be said to have emerged in Nigeria during the 1964 federal elections and reached a crescendo in 1965-1966 during the western regional elections. In both elections parties and some key political leaders hired thugs to beat up, maim, kidnap, or murder their political opponents, disrupt campaign rallies, snatch ballot boxes, burn down houses, thumbprint ballot 
papers, disrupt voting in opponents' strongholds, and so on. Many people were killed and violent thuggery reigned throughout the federal elections. Electoral officers disappeared from their offices after receiving the nomination papers of favoured candidates and, on voting day, women became 'pregnant' with ballot papers which they offloaded when they entered the secluded polling booths. At the end, Nigeria had a constitutional crisis as the east had boycotted the election because of the rigging and the physical and structural violence in the electoral process. For three days Nigeria had no head of government as the president, $\mathrm{Dr}$ Nnamdi Azikiwe, found it difficult initially, given the flawed and violent election, to reappoint Balewa as prime minister. He did, however, reappoint him after several days of consultation.

The electoral violence in the western region during the 1965 regional elections emanated from the determination of the leadership of the Nigerian National Democratic party (NNDP) of Chief S L Akintola to retain power at all costs and whether or not the electorate voted for it. In this bid it had the strong backing of the federal government under the Northern People's Congress (party), which wanted to counteract the influence of Chief Obafemi Awolowo and his Action Group, supported by the National Council of Nigerian Citizens (NCNC) of Dr Azikiwe, and with which it formed the alliance called the United Progressive Grand Alliance (UPGA). ${ }^{2}$

The NNDP, supported by the state, rigged the elections to retain power in the western region, but, despite the allegations of rigging, the elections were declared legal. The announcement of the results was followed by widespread disturbances in the west in which many people were killed and property destroyed (Ojiako 1979, p 3; Ojo \& Azeez 2002, p 209). The violence, popularly known as 'Operation Wet-e' (pour fuel and burn), continued from November 1965 to 15 January 1966, when the first military coup occurred in Nigeria, overthrowing the constitutional order and inaugurating the first long stretch of military dictatorship in the country (from 1966-1979). Commenting on the reactions of Nigerians to the 1964 general elections and the 1965 western regional elections, Chief Bola Ige (1992, p 37) asserted:

... the election rigging of 1964 (at Federal level) and of 1965 were seen by the majority of Nigerians as despicable acts and the victory of anti-democratic forces. So they reacted, first by the general boycott of 1964, and secondly by the famous operation 'wet-e' in 1965 (in which properties of those suspected of selling out were set on fire).

2 Chief Awolowo was jailed during the election on trumped up charges. 
Ochoche (1997) observed that the western regional election crisis of 1965-1966 'remains the worst single period of electoral violence in the history of Nigeria'. By the time of military intervention in 1966 it had grown to 'epidemic proportions' (Dudley 1973, p 114). According to a former chief justice of Nigeria the 1965 elections were riddled with malpractice, aggravated by violence from both the NNDP and UPGA, but especially from the NNDP, which was the party in power. The UPGA candidates who lost the election did not bother to go to the courts, which were controlled by the NNDP and its federal ally, they simply refused to accept the results, rendering the government of Chief Akintola of questionable legitimacy. The UPGA and its millions of supporters took to the streets 'threatening, burning or maiming any member of the government party they could corner in the bush or in a back-garden. Life in those days was certainly not safe in the streets of Ibadan, Ife or Ikeja. Cars of known party stalwarts were set ablaze. Unpopular customary court Presidents were slaughtered like rams' (Ochoche 1997, p 17). This violence earned the western region (Yoruba land) the label 'Wild-Wild-West'. But this author personally sees the action as meriting the label 'Wise-Wise-West', as the people justifiably used physical violence to rid themselves of the anti-democrats who had used structural violence to impose themselves as rulers.

The military rule ushered in by the 1965-66 western regional electoral violence only ended in 1979 when General Obasanjo's military regime supervised a federal election that paved the way for his famous voluntary handover to the civilian government led by Alhaji Shehu Shagari of the National Party of Nigeria. Given the fact that the military played midwife to the election and transition there was not much violence, though the election attracted criticism as the Supreme Court delivered a controversial decision on the winner, based on a questionable mathematical 'theory' introduced to determine the winner instead of the use of an Electoral College, as provided for in the Constitution.

During the 1983 federal elections, supervised by the NPN government led by President Shehu Shagari, electoral violence resurfaced. The NPN was determined to remain in power, while most Nigerians wanted a change in government. Even in the north the electoral slogan was 'chanji' (change). Thus, violent thuggery re-emerged and the elections were rigged, even by Federal Election Commission of Nigeria officials, with the support of the police. The people reacted once more by pouring into the streets in anger and the government ordered the police to shoot on sight. The military once more seized the opportunity to halt Nigeria's march to democracy and it would be another ten years (1993) before Nigerians had the opportunity to vote again.

The Babangida government organised the most secure, peaceful, free and fair federal elections in Nigeria's history but in the end Babangida annulled the presidential election (won by Chief M K O Abiola) in pursuit of his personal 
ambition to become a civilian president and the northern agenda of not returning power to the south. Babangida stepped aside in August of the same year, paving the way for an interim government (led by Chief Ernest Shonekan), which was pushed aside in a palace coup by General Sani Abacha after three months. General Abacha was planning to transform himself into a civilian president when death came calling and General Abdulsalami Abubakar became head of state and effected a transition to democracy within six months of taking over government. Again, because Nigerians were tired of military rule and because the military oversaw the transition, there was little violence during the 1999 election which brought Chief Olusegun Obasanjo to power on 29 May.

The Obasanjo government conducted the 2003 elections, during which electoral violence resurfaced. This time the violence included political assassination. Election rigging, with the direct involvement of the nation's socalled Independent National Electoral Commission (INEC), was raised almost to a 'virtue'. Favoured persons were made governors, while some who had never before contested an election were made senators. All these factors led to corruption and misgovernance.

The country hoped for a better election in 2007, believing that because the president had served his two terms the incumbency factor would be greatly reduced. But as the election period drew near President Obasajo told surprised Nigerians, other Africans, and the world that the 2007 elections would be a 'door-die' affair. These words set the stage for the electoral violence that made the 2007 election the worst in Nigeria's history, surpassing the events of 1965-1966.

The nature of the violence had changed, though. Before 2003, it was mainly carried out by the masses in angry reaction to election rigging or it was executed by party thugs. But from 2003, and especially in 2007, godfathers, governors, local government chairmen and candidates for legislative houses recruited followers, thugs, and assassins armed with sophisticated weapons and unleashed them on their opponents and on society.

The state was also grossly irresponsible during the 2007 elections, with the presidency promoting violence. INEC, in collusion with the ruling People's Democratic Party (PDP) and the presidency, with help from the police, rigged elections for the PDP and favoured candidates. The president, governors, commissioners, and ministers were personally involved in generating electoral violence - physical, psychological, and structural. An observation by Egbokare (2007, p 24) summarises the ugly developments.

Since 1979, things appear to be getting worse. I think what was different this time was that it was not just a thug affair. Governors and their Deputies, Ministers, in fact, the high and mighty in the 
society were involved in the field operations once left to thugs. They personally participated in snatching ballot boxes, thumb-printing, and disruption of voting. The Police as usual provided cover. The reason these individuals got involved directly was because thugs were neutralized by the people's resolve in a number of places. In one instance, the Police and thugs of a certain party had dispersed voters with tear-gas and were busy thumb printing. In another instance, voting stopped at a polling station after only three people had voted. Voter intimidation was rampant, ballot boxes were burnt, fire arms were freely used and of course lives were lost.

The sad message of this review of the history and evolution of electoral violence in Nigeria is that things are not improving. Instead, they are getting worse Politicians, electoral administrators, and government at all levels are not learning any useful lessons from history. It is sad, but this truth and sadness must spur the resolve in Nigerians to get things right in future.

\section{THE 2007 ELECTIONS: A BRIEF OVERVIEW}

\section{Preamble}

Nigerians looked forward to the 2007 elections with hope for changes in their electoral fortunes and the wish to have better leaders, who would improve their lives. Given the disappointing outcome and the problems attendant on the 2003 elections, they expected constitutional and electoral reforms and a better-organised election in 2007. However, Obasanjo's third-term bid stalled plans to amend the 1999 Constitution and there were no electoral reforms, only an increase in the number of political parties from the three in 1999 to 50. The Electoral Act of 2002 was merely amended to become the Electoral Act 2006. Since Nigeria's Constitution provides for a four-year tenure for all elective positions, those elected into office in 2003 were due for change in 2007. The administration of the election fell on INEC, which had conducted the 2003 elections. The posts to be filled were those of president, 109 senators and 290 House of Representative members. Nigerians had high expectations of achieving a secure, peaceful, free and fair civilian-tocivilian handover in order to break the jinx of the national inability to achieve this since independence in 1960.

\section{Preparations}

INEC prepared for the elections, registering voters and political parties, printing ballot papers, training its officials and recruiting ad hoc staff, procuring ballot 
boxes, and locating polling booths and collation centres. While this took place political parties began their primaries in November 2006 to elect their standard bearers, with some imposing favoured candidates as 'winners'. For example, Alhaji Musa Yar'Adua, who had not been a strong contender, won the nomination for the PDP's presidential slot. Campaigns began in earnest from December 2006, heralding the assassination of opponents and violent rallies by armed thugs.

\section{Voting}

Voting for governors and state houses of assembly candidates took place on 14 April 2007, while the presidential and National Assembly elections took place on 21 April. The two elections were marred by brazen and open irregularities, violence, and corruption, much of which were executed with impunity.

In some places elections were postponed for one reason or the other. For example, in Lagos State senatorial elections were postponed in two of three districts because some political party logos were omitted from ballot papers. In Rivers, Sokoto, Abia, Ogun, Delta, Bayelsa and Jigawa states INEC postponed National Assembly elections because of missing party logos and candidate names, which INEC blamed on a 'printer's error' - a situation described by Chief Bisi Akande (national chairman of the Action Congress) as 'disgraceful' (Sunday Punch, Lagos, 22 April 2007, p 9).

The violence and irregularities experienced during the 14 April gubernatorial elections resulted in a low turnout for the presidential election. Among the problems were the late arrival of voting materials, the absence of INEC officials from several polling booths, and late starts in voting. Even during the presidential election voting started very late in several areas, sometimes as late as midafternoon (Sunday Punch, Lagos, 22 April 2007, p 8).

\section{Vote Counting and Announcement of Results}

In the gubernatorial election several candidates were imposed as 'winners' by INEC, for instance in Anambra and Kogi states. In the presidential election Alhaji Musa Yar'Adua was declared winner, to the chagrin of other contestants, who cried foul.

\section{Aftermath}

Spontaneous violence greeted the announcement of results in several states of the federation and more assassinations followed. Several cases were filed in the electoral tribunals at the state level. General Buhari, who contested the presidential election for the All Nigeria People's Party, and Alhaji Atiku Abubakar, the Action 
Congress candidate, went to the Election Tribunal where hearings began on 17 July. Atiku's case was based on the exclusion of his name from the ballot paper and other manipulations of the electoral process (Nigerian Tribune, Ibadan, 13 July 2007, pp 1, 4).

The widespread irregularities generated popular resentment of ruling bodies formed on their basis; and eroded citizens' confidence in INEC, the federal government, and the democratic process. As at October 2007 two gubernatorial processes (in Kogi and Anambra states) had been annulled by election tribunals. The Anambra governor, Chief Uba, of the PDP, had to vacate his office in favour of Dr Peter Obi of the All Progressive Grand Alliance (APGA). In Kogi State incumbent Governor Ibrahim Idris has appealed against the judgement delivered by the tribunal chairman, Justice Ibrahim Bako, on 10 October 2007, ordering a fresh election (Babajide 2007, pp 1, 4).

Table 2

Cases Challenging the April 2007 Election Results

\begin{tabular}{|l|c|}
\hline State & Number of Cases \\
\hline Anambra & 99 \\
\hline Borno & 8 \\
\hline Ebonyi & 17 \\
\hline Edo & 32 \\
\hline Imo & 13 \\
\hline Gombe & 12 \\
\hline Kaduna & 21 \\
\hline Kano & 43 \\
\hline Katsina & 44 \\
\hline Kogi & 46 \\
\hline Ogun & 80 \\
\hline Oyo & 19 \\
\hline Kwara & 21 \\
\hline Plateau & 28 \\
\hline Rivers & 68 \\
\hline Yobe & 6 \\
\hline
\end{tabular}

Source: Ololajulo 2007, p 22 
The opposition parties and some members of civil society planned mass action on 1 May (Workers' Day) to protest the sham elections but these did not take place as the police ordered state commissioners to clamp down on all protests in terms of the Public Order Act (The Punch 1 May 2007, p 6).

\section{Assessment}

Alhaji Atiku Abubakar, Nigeria's vice-president and AC presidential candidate, describing the general elections as a sham (Nigerian Tribune 22 April 2007, p 6), vowed to challenge the result. The Nigerian Labour Congress, and the Trade Union Congress, the most powerful labour organisation in Nigeria, formally rejected the outcome of the elections (Nigerian Tribune 1 May 2007).

The Transition Monitoring Group, described the elections as a charade, insisting that the Obasanjo government, in close collusion with INEC and the PDP, programmed the election process to fail (Idasa 2007, p 20). The Action Congress termed the elections the worst in the history of Nigeria. The party's publicity secretary, Alhaji Lai Mohammed (quoted in The Punch 9 May 2007, p 14), said President Obasanjo had bungled a chance to ensure a peaceful and credible transfer of power from one civilian government to another. In his words:

Whatever happens on May 29, 2007, the truth will remain that Nigeria is yet to achieve a credible transfer of power from one elected leader to another, since what transpired under Maurice Iwu's INEC couldn't be described as an election ... Whether in 1979, 2003, or 2007, President Obasanjo has only succeeded in redefining the concept of elections to mean brigandage, daylight robbery, and a do-or-die affair.

The European Union condemned the elections, stating that the presidential election had been worse than the gubernatorial election. The European Union Election Observation Mission and several other national and international observers said the elections fell short of basic international and regional standard for democratic elections.

[The elections] ... were marred by poor organization, lack of essential transparency, widespread procedural irregularities, significant evidence of fraud particularly during the result collation process, voter disenfranchisement at different stages of the process, lack of equal conditions for contestants and numerous incidents of violence. As a result, the elections have not lived up to the hopes and 
expectations of the Nigerian people and the process cannot be considered to have been credible.

Idasa July 2007, pp 19-20

Yar'Adua himself publicly recognised and acknowledged on the day of his inauguration as president the fact that the elections were greatly flawed and promised sweeping electoral reforms while calling for a government of national unity.

\section{MANIFESTATIONS OF ELECTORAL VIOLENCE DURING THE 2007 ELECTIONS}

\section{Insight}

Cashmir Igbokwe, a columnist for Sunday Punch, who asserted that the election 'was war by another name' (22 April 2007, p 17), was not far from the truth. Judging by all that has been published and broadcast in the media, and all that this writer personally witnessed before, during, and after the elections, it is no understatement to say the 1965-66 western regional electoral violence was child's play compared to the scale and depth of the violence experienced in Nigeria in 2007.

The stage was set early for widespread violence when President Obasanjo stated that for him and the PDP the 2007 election was a 'do-or-die affair', a statement as terrifying as it was surprising and unexpected from a leader of his international stature. The other 49 political parties, hundreds of non-PDP candidates and godfathers all over the country got the message, and prepared. The masses of the Nigerian electorate also readied themselves to resist a repeat of the rigging effected by the government during the 2003 elections, as well as any attempt by any party or candidate to intimidate or harass them.

As the physical violence began to unfold, starting with the assassination of political opponents like Dr Ayo Daramola (PDP gubernatorial candidate in Ekiti State) on 14 August 2006 and Chief Funso Williams (PDP gubernatorial candidate in Lagos State) in July 2006, high-profile candidates began to apply for police protection. The demands increased after the bombing of the home of Senator Patrick Osakwe in Delta State on 24 November 2006 and the bombing, also in Delta State, of the houses of two House of Representative aspirants Nduli Elumelu and Theodora Giwa-Amu. The then inspector general of police said he could not meet all the demands. The electoral candidates also appealed to the police to stem the rising tide of political assassinations and violent clashes ravaging the country. Even the new Sultan of Sokoto, Alhaji Sa' ad Abubakar III, appealed to politicians to eschew violence in their campaigns and stop raising tension, fear, and anarchy in the country (Vanguard 7 April 2007). 


\section{Manifestations of Physical Violence}

Physical violence was rife before, during, and after the elections, taking the form of: physical assault, assassinations, disruption of campaign rallies, burning of houses and cars, including government-owned ones, snatching of ballot boxes from polling booths, disruption of voting, destruction of ballot papers in opponents' strongholds, murder, kidnapping and hostage taking, shootouts, raids on voting and collation centres, free-for-all fights and violent protest marches, among others.

For example, the refusal of the INEC resident electoral commissioner in Abia State, Prince Solomon Soyebi, to rig the gubernatorial election for the PDP candidate, Chief Onyema Ugochukwu, because the former was a born-again Christian, led to Ugochukwu slapping Soyebi and calling him a 'big fool'. Ugochukwu's thugs also dealt mercilessly with Prince Soyebi, who had to be rescued by members of the Nigerian Air Force (The Nation On Sunday 22 April, $p$ 14). In Kano State thugs brandishing cutlasses and swords invaded several polling booths, disrupting voting during the presidential election. In Edo State Adams Oshiomohle, immediate past president of the Nigerian Labour Congress and the AC's gubernatorial candidate, and his convoy were attacked at Auchi on 21April by armed thugs sponsored by the PDP. His orderly was disarmed and beaten into a coma and his vehicles were damaged (Sunday Vanguard 22 April 2007, p 5). Also in Edo State there were shootouts between armed supporters of different parties. One occurred in Akoko-Edo, where soldiers arrested 10 people during a shootout between PDP and AC supporters (Sunday Vanguard 22 April 2007, p 5).

In Delta State, by 18 April, several houses had been burnt down, including the country home of a serving commissioner, Evans Iwhurie. A couple visiting the family were burnt to death. By the same date four more people had been killed and 20 wounded (Sunday Vanguard 22 April 2007, p 14). Also in Delta State assassins shot and wounded a PDP leader, Dr Nelson Ejakpori (The Guardian 7 April 2007), while in Bayelsa State Stephen Divei of the PDP narrowly escaped bullets rained on him by assassins who trailed him for a whole day (The Guardian 29 May 2007).

At Okelewo in Ogun State hoodlums destroyed two ballot boxes, scattering the ballot papers on the main road (Sunday Vanguard 22 April 2007, p 5) and in Abeokuta, capital of Ogun State, members of different political parties engaged in free-for-all fights, using guns, cudgels and cutlasses, and wounding 12 people (Nigerian Tribune 14 April 2007; Vanguard 17 April 2007).

While voting was in progress during the presidential election an attempt was made to blow up INEC headquarters in Abuja with a tanker loaded with explosives. In Katsina State the INEC office in Zango Daura Local Government 
Area was set alight (Sunday Punch 22 April, p 8). In Minna, in Niger State, armed thugs invaded several polling booths, snatching 15 ballot boxes and destroying the ballot papers (Sunday Punch 22 April, p 15). In Kaduna State during the presidential election three people were killed by party thugs in the Karaye area of Zaria (Sunday Punch 22 April, p 15) and a man found in the Obankpa area of Delta State with pre-prepared tally sheets was shot dead (Sunday Punch 22 April, p 13). In Katsina State seven houses were burnt down during the presidential election (Sunday Tribune 22 April 2007, p 4).

When the result of the gubernatorial election was announced in Ondo State, declaring Governor Segun Agagu, the PDP candidate, re-elected, supporters of the Labour Party took to the streets to protest against the defeat of Dr Olusegun Mimiko in what they believed to be a rigged election. Vehicles and houses, most of them belonging to a PDP chieftain, were burnt. Also razed were the houses of Senator Gbenga Ogunniya and Chief Ojo Akinpelu (chairman, Ondo Local Government). The INEC office at Akure was destroyed by irate youths. The violence spread like wildfire from Akure to Ondo, Akoko, Ile-Oluji, Oke-Igbo, Idanre and Okitipupa (The Nation On Sunday 22 April 2007, p 34).

On 20 April armed men, believed to have been angered by the role the police force was playing in the election, ambushed and killed nine members of the Nasarawa Police Command who were heading for their duty post in preparation for the presidential election (The Nation On Sunday 22 April 2007, p 34). Earlier, in Osun State, the campaign office of Engineer Aregbesola, the AC gubernatorial candidate, had been raided and ransacked by police and soldiers, who took away vital electoral documents, including election results sheets officially given to the AC by INEC. AC members believed that the seizure of the documents was meant to facilitate the rigging of elections (The Nation On Sunday 22 April 2007, p 34).

In Benue State on 14 April an aide of ANPP gubernatorial candidate Professor Daniel Saror was gunned down in his residence in the state house of assembly quarters (Sunday Punch 22 April 2007, p 13). In Portharcourt eight people, seven of them policemen, were shot dead at Elelewon and Rumaokoro police stations and vehicles and the two police stations were burnt (Sunday Punch 22 April 2007, p 13). In Edo State eight voters who tried to stop thugs from snatching ballot boxes came under fire, while in Osun State protests against the announcement of the result returning Governor Oyinlola to power led to the death of 16 people, including an 8-year-old girl hit by stray bullets (Sunday Punch 22 April 2007, p 14). ${ }^{3}$

3 For more details on the fraud perpetrated during the elections see Newswatch 20 April 2007. 


\section{Manifestations of Psychological Violence}

Psychological violence took the forms of threats, offensive advertorial, the use of terror tactics, and so on. For example, the statement by then President Obasanjo to the effect that the 2007 elections would be do-or-die affair did a lot of psychological violence to the elections. Nigerians never expected such words from a man they expected to play the role of a statesman and father of the nation. The statement made people fear for their safety if they contested or participated in the elections.

The sight of armed thugs brandishing all forms of weapons, killing and maiming innocent citizens whose only 'crime' was to perform their civic patriotic duties, also wrought psychological violence. Security agents threatened, harassed, arrested, beat and killed citizens. The heavy presence of heavily armed policemen and soldiers generated voter apathy in many areas. For example, in Ogbomoso town in Oyo State, according to the inspector general of police (IGP), the 'heavy security marred elections in several wards ... as intimidated voters stayed away from polling centres' (The Punch 1 May 2007, p 6).

The order by the then IGP, Sunday Ehindero, to his state commissioners of police to clamp down on people planning or effecting protest marches on 1 May denied citizens the opportunity to air their objections to the way their votes had been stolen. 'I have given orders to my Commissioners of Police all over the Federation to use minimum force, or force that is more than the minimum if the need arises to ensure that we don't have any rally without Police permit outside the designated points,' he said (The Punch 1 May 2007, p 6).

The result of this attitude was the populace was doubly disadvantaged. Not only were the elections rigged, they were prevented by the use of unconstitutional means from protesting.

\section{Manifestations of Structural Violence}

Structural violence occurred in several forms before, during, and after the 2007 elections.

- INEC's incompetent compilation of the voters' register meant that many people (including the writer) were never registered and were thus disenfranchised.

- When the voters' register was displayed hundreds of names were missing.

- Some candidates, among them AC candidate Vice-President Alhaji Atiku Abubakar, were disadvantaged by decisions made by INEC.

- The police and military were used in some areas to harass and intimidate opponents. 
- In several states and polling centres the start of voting was delayed until 3 pm or later. In the presidential election in Abia State, for example, Governor Orji Uzo Kalu, Progressive People's Party (PPA) presidential candidate did not vote until $7 \mathrm{pm}$ because voting materials arrived late. He believed that the late arrival of election materials in his state was a deliberate ploy to cheat him and the entire Igbo race. He added that in the following two months the entire Igbo race would meet to decide whether or not the Igbo people would remain part of Nigeria because 'what has happened is a threat from INEC and the FG [federal government] to the Unity of Nigeria' (Sunday Tribune 22 April 2007, p 5). In Ibadan voting did not commence in several areas until 12 noon on 21April. In Imo State, voting materials for the presidential election only arrived at Owerri (the state capital) at 4pm (Sunday Tribune 22 April 2007, p 50).

- Names of several candidates and political party logos were missing (excluded) from the ballot paper in several states, leading to the postponement of elections in those states. For example, the National Assembly election in Abia State was postponed in six of eight federal constituencies (Sunday Tribune 22 April 2007, p 5).

- Voting materials were not provided at all for elections in some areas. For example, in Oyo town, Oyo State, the Alaafin of Oyo complained bitterly about the non-provision of voting materials for the House of Representatives election (Sunday Tribune 22 April 2007, p 6).

- There was a mix-up with the ballot papers printed for election in some areas, leading to the cancellation of elections in those areas - the NigerEast and Niger-South senatorial zones were two examples.

- Serial numbers did not appear on the ballot papers in some states, making the detection of rigging impossible (Sunday Punch 22 April 2007).

- Photographs of some of the candidates were not included in the ballot papers for some elections. This negatively affected the electorate in their choice of candidates.

- Inadequate provision of voting materials to hundreds of polling centres disenfranchised hundreds of Nigerians.

- The behaviour of INEC, the police, and the presidency was clearly partisan.

\section{CONCLUSION}

There were myriad consequences of electoral violence in Nigeria during the 2007 general elections. They included voter apathy, ${ }^{4}$ the destruction of lives and property, loss of confidence in the democratic process, many contestants forced into hiding, a rise in political tension, increased general insecurity, human rights 
abuses, Nigeria's failure to give leadership to Africa on best democratic practices, denting of Nigeria's national image and a government handicapped by a legitimacy crisis.

What are the factors responsible for the electoral violence? In 2002 the Academic Staff Union of Universities attributed it to 'deepening poverty, unemployment, and hunger, retrenchment resulting from privatization of public property, manipulation of ethnic loyalties' (Albert 2007, p 132). Albert adds 'religious fundamentalism, elite fragmentation, commoditization of politics, the framing of Nigerian elections as "zero-sum" events, and lack of independence of the Judiciary, Police and successive election administration bodies'. To these we can add the desire of politicians to win election at all costs, disregard for the rules of the political game, the inordinate desire of incumbent leaders either to hold their positions or to impose their surrogates, undemocratic internal party workings and practices such as the imposition of candidates, arrogance, high rewards for political office holders, the high cost of elections and the need to ensure that expenditure is not wasted but instead brings huge returns, clashes of egos, such as that between Obasanjo and Abubakar, and the fact that being in government ensures that the winner and his or her people get their share of the national cake. All these factors make people attach tremendous importance to political power and its acquisition. As Mackintosh (1965, p 21) rightly observes:

To win an election means that you, your village, tribe, or region obtains all the top posts, the lucrative contracts, roads are tarred, scholarships are provided, wells are dug, and new forms of industry introduced. To lose is to surrender not only the good things but many of the necessities of life.

Claude Ake (1964, p 24) agrees, stating:

Those who win state power can have all the wealth they want even without working, while those who lose the struggle for state power cannot have security in the wealth they have made even by hardwork. The capture of state power inevitably becomes a matter of life and death. That is one reason why our politics is so intense, anarchic, and violent.

4 This was probably felt most in Edo State where the turnout for the presidential election was very low as a result of the violence experienced in the state during the 14 April when more than seven people were shot dead by armed thugs. See Sunday Vanguard 22 April 2007, p 5. 
If, however, this writer is asked to point out one reason why Nigeria has continued to experience electoral violence it is the fact that officials and citizens who plan and unleash violence on all of us are not punished and held accountable for their unpatriotic and undemocratic actions. Instead they enjoy immunity, which blocks reform and, at the same time, denies justice to the victims of their violence. There is therefore a general loss of confidence by the people in public institutions - courts, the police, INEC, government, tribunals, and the bureaucracy, which are regarded as compromised, corrupt, partisan, and ineffectual. Thus people react violently to structural (and psychological) violence emanating from the state. There is criminal failure of public institutions, especially those responsible for investigating and prosecuting crimes against the people and the state. Our electoral institutions are failed structures, lacking rudimentary integrity.

In order to combat the ugly phenomenon of electoral violence in Nigeria, which has become a great threat to the country's unity, external image, national security, and democratic consolidation, the first thing is to impose serious punishment, including life imprisonment, for election rigging, the recruitment and sponsorship of thugs, the planning and execution of assassinations, and other criminal forms of armed politics.

Second, it is essential that civil society mobilise to ensure that the federal government enacts and implements the Freedom of Information Act, which has thus far taken nine years to make its way through the National Assembly and the presidency. This law will make it possible for Nigerians, especially the media, to burst the cocoon of secrecy which enables government officials to hide evidence of criminal and illegal activities and thereby get away with murder.

Third, the ongoing electoral reform panel needs to dig deep and wide and operate truly independently in the execution of its assignment, to ensure that henceforth Nigeria conducts only secure, peaceful, free and fair elections that enhance political stability, national security, and the consolidation of democracy.

Fourth, the Yar'Adua administration, as part of ongoing electoral reform, must institute nation-wide judicial inquiries into the violence and corruption that surrounded the 2007 elections, exposing and prosecuting the sponsors of armed gangs and violence.

Fifth, the creation of two million jobs a year for the next four years is critical to dry up the pool of unemployed, hungry and angry youths in the country, which readily serves as a recruiting ground for all forms of crime. Sixth, Nigerians must resolve today to do away with armed politics and election rigging. Seventh, the culture of political debate must be enthroned to promote political tolerance and do away with ethnic, religious, and personality issues in election periods. Post2007 elections must be programmed not only to be secure, peaceful, free and fair, but must be seen by Nigerians, Africans, and the world at large to be so. 
Finally, there is an urgent need for Nigeria's leaders to embark on massive education, enlightenment and mobilisation of the country's citizens, inculcating in them the knowledge of a democratic ethos and principles and empowering them always to uphold and defend truth, law, justice, and democracy. Without these actions little can be achieved in the bid to make politicians play the political game according to the rules. The ancient words of Aristotle (1253, p 30) are instructive:

For man, when perfected, is the best of animals, but when separated from law and justice, he is the worst of all; since armed injustice is the more dangerous, and he is equipped at birth with arms, meant to be used by intelligence and excellence, which he may use for the worst ends. That is why, if he has not excellence, he is most unholy and the most savage of animals, and the most full of lust and gluttony. But justice is the bond of man in states, for the administration of justice which is the determination of what is just, is the principle of order in political society.

Nigerians must insist on the radical transformation of Nigeria into a political society built on the principle of order established by law. This is where President Musa Yar'Adua's current crusade for the enthronement of the rule of law and due process holds out a ray of great hope for peace, justice, democracy, and future free and fair elections devoid of electoral violence.

\section{- REFERENCES}

Ake, C. 1964. 'The Political Question'. In O Oyediran (ed). Governance and Development in Nigeria: Essays in Honour of Professor Billy J. Dudley. Ibadan: Oyediran Consult International.

Akintola, B. 2006. 'Politics By Elimination: Implications of Political Violence on Nigeria's Nascent Democracy'.The Nigerian Army Quarterly Journal 2(4), December.

Akzin, B. 1960. 'Election And Appointment'. American Political Science Review LIV(3). Albert, I. 2007. 'Reconceptualising Electoral Violence in Nigeria'. In I Albert, D Marco \& V Ochoche. 1997. 'Electoral Violence and National Security in Nigeria'. Africa Peace Review 1(1), April.

2007. 'Reconceptualising Electoral Violence In Nigeria'. In I Albert, D Marco, and V Adetula (eds). Perspectives on the 2003 Elections in Nigeria. Abuja: Idasa and Stirling-Holding Publishers. 
Anifowose, R. 1982. Violence And Politics In Nigeria; The Tiv And Yoruba Experience. New York: Nok Publishers.

Aristotle. 1253. Nicomachean Ethics.

Audi, R. 1971. 'On The Meaning and Justification of Violence'. In J A Shaffer (ed). Violence. New York: David McKay.

Babajide, J. 2007. ‘Tribunal Annuls Kogi Governor's Election'. Nigerian Tribune 11 October.

Corsini, R J. 1999. The Dictionary of Psychology. Brumer, Taylor and Francis Group. Paraphrased in B Akintola, 'Politics By Elimination: Implications of Political Violence on Nigeria's Nascent Democracy'. The Nigerian Army Quarterly Journal 2(4), December.

Degenaar, J. 1990. 'The Concept of Violence'. In N C Manganyi and A du Toit (eds). Political Violence And the Struggle In South Africa. London: Macmillan. Diamond, L et al (eds). 1997. Transition Without End: Nigerian Politics And Civil Society Under Babangida. Ibadan: Vintage Publishers.

Dudley, B. 1973. Instability and Political Order: Politics And Crisis In Nigeria. Ibadan: Ibadan University Press.

Egbokare, F. 2007. 'Dancing Naked In The Streets'. Sunday Tribune 22 April.

Freud, S. 1939. 'Thoughts For The Times On War And Death'. Collected papers Of Sigmund Freud Vol 4. New York: Basic Books.

Galtung, J. 1991. 'Violence and Peace'. In P Smoker, R Davies \& B Munske (eds). A Reader In Peace Studies. Oxford: Pergamon Press.

Gurr, T R. 1970. Why Men Rebel. Princeton: Princeton University Press.

Hollard, J, L Doob, N Miller et al. 1939. Frustration And Aggression. New Haven: Yale University Press.

Hook, S. 1934. 'Violence'. In Encyclopedia of The Social Sciences 20.

Idasa. 2007. Conflict Tracking Dossier: A Quarterly Review 7 July.

Igbokwe, C. 2007. 'Big Issues In UK And Nigeria's Elections'. Sunday Punch 22 April.

Ige, Chief Bola. 1992. 'Democratic Experiments In Nigeria, 1960-1990'. In A Fasoro, D Haastrup \& A Otubanjo. Understanding Democracy. Ibadan: Bookcarft Ltd. Kean, J. 2004. Violence And Democracy. Cambridge: Cambridge University Press. Kolawole, D. 1988. 'Political Violence: A Case Study of Ondo State'. In V Ayeni \& K Soremekun (eds). Nigeria's Second Republic. Lagos: Daily Times.

Leiden, C \& K Schmitt (eds). 1968. The Politics of Violence. Englewood Cliffs: Prentice-Hall.

Lewis, A. 1965. Politics In West Africa. New York: Oxford University Press. Mackintosh, J A. 1965. 'The Struggle for Power in Nigeria'. Transition 22.

Mayo, H. 1960. An Introduction To Democratic Theory. New York: Oxford University Press. 
Mitee, B. 'Election Violence In The Niger Delta: An Ogoni Experience'. In I Albert, D Marco, and V Adetula (eds). Perspectives on the 2003 Elections in Nigeria. Abuja: Idasa and Stirling-Holding Publishers.

Nwolise, O B C. 2007. '2007 Elections And The Tribunals'. The Guardian, Lagos, May 7.

— . 'Political Parties And The Electoral Process'. In V Ayeni \& K Soremekun (eds). Nigeria's Second Republic. Lagos: Daily Times.

Ochoche, S A. 1997. 'Electoral Violence and National Security in Nigeria'. Africa Peace Review, Journal of the Centre for Peace Research and Conflict Resolution 1(1), April.

Ojiako, J. 1979. 13 Years of Military Rule. Lagos: Daily Times Publications.

Ojo, E O \& A Azeez. 2002. 'The Military And Democratic Transition In Nigeria'. Nigerian Journal of International Affairs 28(1\&2).

Ololajulo, B. 2007. 'Niger Delta Since May 29, 2007: A Review'. Conflict Tracking Dossier: A Quarterly Review 7, July.

Osaghae, E. 2002. Crippled Giant: Nigeria Since Independence. Ibadan: John Archers Publishers.

Post, K \& M Vickers. 1973. Structure And Conflict In Nigeria 1960-1966. London: Heinemann.

Sklar, R. 1966. 'Nigerian Politics: The Ordeal of Chief Awolowo, 1960-1965'. In G Carter (ed). Politics In Nigeria: Seven Cases. Harcourt, Brace and World Incorporation.

Wolff, R. 1969. 'On Violence'. Journal of Philosophy 16(19), 2 October.

\section{Newspapers}

Nigerian Tribune, Ibadan.

Sunday Punch, Lagos.

Sunday Vanguard.

The Guardian.

The Punch.

The Nation On Sunday.

Vanguard. 